\title{
Association Between Toluene Inhalation Exposure and Demography Towards Risk of Neurotoxic: A Cross-Sectional Study at Plastic Sack Industry Workers in Indonesia
}

\author{
Abdul Rohim Tualeka ${ }^{1}$, Dwi Ananto Wibrata ${ }^{2}$, Bahrul Ilmi $^{3}$, Ahsan $^{4} \&$ Pudji Rahmawati ${ }^{5}$ \\ ${ }^{1}$ Department of Occupational Health and Safety, Faculty of Public Health, Airlangga University, Surabaya, \\ Indonesia \\ ${ }^{2}$ Department of Nursing, Health Polytechnics of Ministry Health, Surabaya, Indonesia \\ ${ }^{3}$ Health Polytechnics of Ministry Health Banjarmasin, Indonesia \\ ${ }^{4}$ Faculty of Nursing, University of Brawijaya, Malang, Indonesia \\ ${ }^{5}$ Department of Development of Islamic Society, State Islamic University Sunan Ampel, Surabaya, Indonesia \\ Correspondence: Abdul Rohim Tualeka, Department of Occupational Health and Safety, Faculty of Public Health, \\ University of Airlangga, Surabaya, Indonesia. E-mail: inzut.tualeka@gmail.com; abdul-r-t@fkm.unair
}

Received: October 16, 2018 Accepted: December 20, 2018 Online Published: January 7, 2019

doi:10.5539/gjhs.v11n2p20 URL: https://doi.org/10.5539/gjhs.v11n2p20

\begin{abstract}
Toluene as a chemical often used by industry has effects that are harmful to the human body. One known effect was neurotoxic. Plastic industry workers are always exposed to toluene with a neurotoxic risk. Research on toluene exposure towards neurotoxic risk has never been done in Indonesia.The research subjects were printing workers in the PT X plastic sack industry. The design was cross-sectional with simple random sampling obtained 32 workers. Toluene concentration was measured using a gas chromatography device while the neurotoxic risk was measured using Q18 Questionnaire from German. The majority of the study subjects aged range of 36-45 years, worked more than 18 years, sometimes used personal protective equipment (PPE), and had nutritional status with criteria for overweight $(\geq 23.0-24.9)$. Demographic factors such as age, working period, personal protective equipment (PPE) and nutritional status have a significant relationship with neurotoxic risk. Indoor toluene concentration also had a significant relationship with neurotoxic risk. Continuous toluene exposure could cause apoptosis/damage to the myelin sheath in the nerves so that it can cause neurotoxin risks such as difficult to concentrate, emotional, dementia and sleep disturbances. Toluene exposure in plastic bag workers can cause a risk of neurotoxins such as difficult to concentrate, dementia, and sleep disturbances. Plastic sack workers are required to use PPE regularly (especially masks) to reduce the risk of neurotoxins through toluene inhalation.
\end{abstract}

Keywords: Germany Q18 Questionnaire, inhalation, neurotoxins, plastic sack industry workers, toluene

\section{Introduction}

Toluene is a type of volatile, colorless and commonly used aromatic hydrocarbon used as a paint solvent, a mixture of gasoline, nail polish, and as a solvent in the printing business. Toluene enters the body through 3 pathways, inhalation, ingestion and skin contact. The main target of toluene is the Central Nervous System (CNS). Symptoms that may arise are fatigue, easy drowsiness, headaches, and nausea (ATSDR, 2015).

Low toluene exposure to nerves can cause neurological disorders. Neurological disorders due to toluene exposure consist of two types, neurotoxic and neuropathic (Pratamasari, 2015). Neurotoxic is defined as an adverse change or functional impairment in the nerves, both the central nervous system and the peripheral nervous system caused by exposure to chemicals, physical and biological agents better known as neurotoxic or neurotoxic substances. This disorder results in changes in memory, attention, mood, disorientation, thinking deviations, and somatic, sensory, and cognitive functions as a neurotoxic effect due to neurotoxic use.

There are several studies showing the relationship between toluene exposure and the risk of neurotoxins. Workers exposed to organic solvents have twice the risk of a diagnosis of neurological and/or psychiatric disability when compared to workers not exposed to toluene (Que Hee, 1993). Research on rabbits showed damage and apoptosis in brain cells with toluene exposure for 3 hours (Demir, 2017). Long-term abuse of 
toluene exposure can also cause dementia, cerebellar ataxia, corticospinal tract dysfunction, and cranial neuropathies (Filley, 2004). There is a complaint in the nervous system that often occurs in 4 exposed group respondents at glue industry, (66.67\%) of respondents had a short memory (forgetfulness), often feel depressed for no particular reason, have abnormal heartbeat and headaches (Agustina, 2016).

Research on toluene exposure to neurotoxic risks, especially in the plastic sack industry has never been done in Indonesia. Therefore, researchers are interested in analyzing the relationship between toluene exposure and neurotoxic risk in printing workers in the PT X Sidoarjo Plastic Industry.

\section{Methods and Materials}

\subsection{Research Subject}

The research subjects were printing workers at PT X plastic bag industry. The inclusion criteria were willing to take part in the study, not being sick in the last 2 weeks and working period of at least 1 year. These study used a cross-sectional design with population sampling 32 research subjects were obtained at printing section. The location of this research was in the PT X plastic sack industry in Sidoarjo, East Java. Before data collection was carried out, this study had been approved by the ethics committee at the Public Health Faculty, Airlangga University Surabaya with protocol ethics approval number 545-KEPK.

\subsection{Instrument and Measure for Variable}

Subjects data were collected in the form of demographics such as age, length of work, length of service, nutritional status and use of PPE (Personal Protective Equipment). Nutritional status was carried out by measuring BMI: $\mathrm{TB}^{2}(\mathrm{~m}) / \mathrm{BB}(\mathrm{kg})$ or worker weight/height of workers2 in units of squared meters $\left(\mathrm{m}^{2}\right)$. The BMI standard for the Asia Pacific was a. obesity II $(\geq 30.0)$, b. Obesity I $(25,0-29,9)$, c. overweight $(\geq 23.0-24.9)$, normal (18.5-22.9) and thin $(<18.5)($ WHO,2000).

In addition, research subjects also measured the toluene concentrations and the risk of neurotoxic events. Toluene concentration was the amount of $\mathrm{mg}$ toluene per $\mathrm{m}^{3}$ of air in the work environment using a gas chromatography-flame ionization detector device (GC-FID) own by the Government of East Java, Surabaya Occupational Health and Safety Technical Implementation Unit (UPT K3) (Tualeka et al., 2018). Measurement of toluene concentration based on 4 locations in the plastic sack industry of PT. X with details of location 1 as many as 8 research subjects, location 2 as many as 11 subjects, location 3 as many as 6 subjects, and location 4 as many as 7 subjects. The measurement was carried out by the professional worker and standard tools by the Surabaya Occupational Health and Safety Technical Implementation Unit (UPT K3) in one time when respondent working. Neurotoxic risk was measured using a German version of the Q18 questionnaire (the German Q18 Questionnaire) totaling 18 questions with criteria: SS (Strongly agree), S (agree), TS (disagree) and STS (strongly disagree) with the cut off point value of 5 or more depended on disturbances or complaints perceived by the research subject. From the literature study linked 21 relevant studies using Q16 Identity overall sensitivity to identify the effects of solvent exposure of $71 \%$, the same number as the main results obtained using the German version of Q18 as a screening tool for neurotoxic events in solvent-exposed workers (Ihrig et al, 2001). So, the questionnaire already has high reliability and validity (Ihrig et al., 2001).

\subsection{Statistic Analysis}

Data analysis used analysis of Pearson Product Moment, Spearman 's Rank and Contingency Coefficient C with SPSS version 20. Correlation numbers ranged from -1 to +1 . The closer to 1 , the correlation is getting close to perfect. The interpretation of correlation numbers is if the value is 0 : none, very weak $(>0-0.25)$, enough $>$ $0.25-0.5)$, strong $(>0.5-0.75)$, very strong $(>0.75-0.99)$ and 1 : perfect (Sarwono, 2006). 


\section{Results}

\subsection{Demographic Characteristics}

Table 1. Demographic Characteristics, Toluene Inhalation Concentration and Neurotoxic Risk of Research Subjects $(\mathrm{n}=32)$

\begin{tabular}{ll}
\hline Variable & Percentage (\%) \\
\hline Age & 3.1 \\
$17-25$ years & 25.0 \\
$26-35$ years & 46.9 \\
$36-45$ years & 21.9 \\
$46-55$ years & 3.1 \\
$>55$ years & \\
Working Period & 59.4 \\
$\geq 18$ years & 40.6 \\
$<18$ years & \\
Use of PPE & 21.9 \\
Never & 78.10 \\
Sometimes & \\
Nutrition Status & 9.4 \\
Obesity 2 & 25.0 \\
Obesity 1 & 28.1 \\
Overweight & 25.0 \\
Normal & 12.0 \\
Thin & \\
Concentration Toluene Inhalation & 25.0 \\
Location 1 $(8,93$ ppm) & 34.4 \\
Location 2 (31,54 ppm) & 18.8 \\
Location $3(9,67 \mathrm{ppm})$ & 21.9 \\
Location $4(9,53 \mathrm{ppm})$ & \\
Neurotoxic risk & 75.0 \\
Have a risk & 25.0 \\
No risk &
\end{tabular}

The average age of respondents was 39.41 years or 39 years, with the youngest age was being 19 years and the oldest age was 59 years. The highest number of workers was in the age range of 36-45 years, as many as $46.9 \%$ (Table 1). There was a fairly strong correlation between age and neurotoxic risk $(\mathrm{r}=0.217$; prevalence risk / $\mathrm{PR}=1.6$ ) (Table 2). A total of $59.4 \%$ had a work-life greater than 18 years while 13 respondents had a service life of fewer than 18 years (Table 1). There was a significant relationship between working period with neurotoxic risk $(\mathrm{r}=0.110 ; \mathrm{PR}=1.14)$ (Table 2). A total of 7 respondents never used personal protective equipment (PPE) at work and 78.1\% sometimes used PPE at work (Table 1). There was a significant relationship between the use of PPE and neurotoxic risk $(r=0.366$; PR $=0.51)$ (Table 2). Distribution of worker data according to the characteristics of nutritional status found the highest number of workers were workers with overweight (28.1\%), followed by Obesity1 and Normal for each of 8 respondents $(25 \%)(\mathrm{r}=0.229 ; \mathrm{PR}=0.89)$ (Tables 1 and 2). 


\subsection{Toluene Concentration and Neurotoxic Risk Frequency}

Of the 32 respondents studied, $34.4 \%$ at location 2 worked at toluene concentrations of $31.54 \mathrm{ppm}$ (Table 1). The value of toluene concentration was below the threshold value but higher than the value of toluene concentration in other locations. As many as $75.0 \%$ have neurotoxic risk due to exposure of toluene compounds in the work environment and majority complaints of neurotoxic were difficult to concentrate, easy to get angry/emotional, heart pounding without pressure, and dementia (Figure 1). Respondents were categorized as having a neurotoxic risk if they have 5 or more complaints from 18 complaints in the Q18 questionnaire. There was a significant relationship between toluene concentration and neurotoxic risk $(\mathrm{r}=0.378)$ (Table 2).

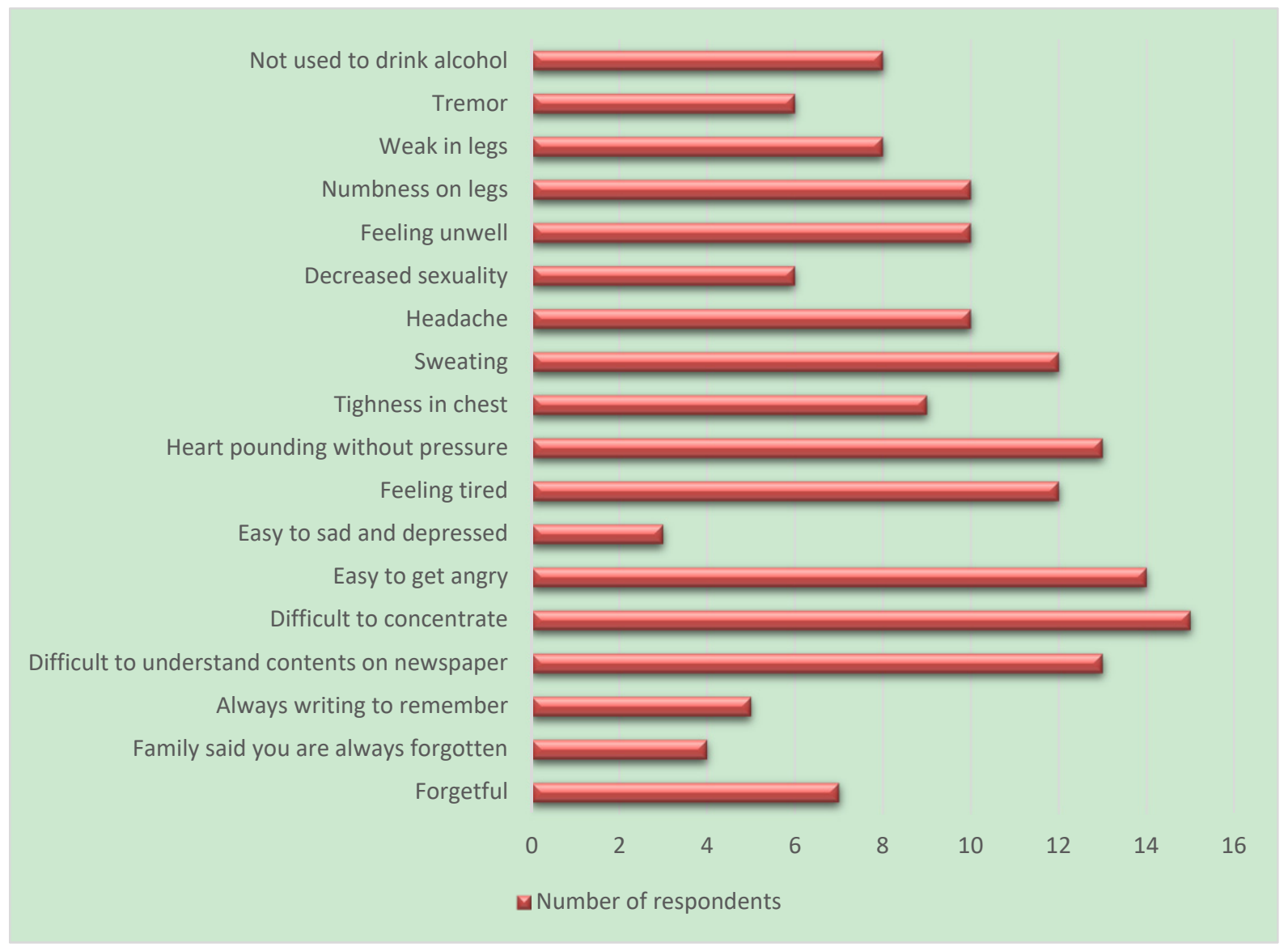

Figure 1. Distribution of Neurotoxic Complaints based on Q18 Questionnaire at Printing Plastic Industry

Table 2. Correlation between Independent Variable with Neurotoxin Risk $(\mathrm{n}=32)$

\begin{tabular}{lll}
\hline Variable & Coefficient Correlation (r) & PR \\
\hline Age & 0.217 & 1.6 \\
Working Period & 0.110 & 1.14 \\
Use of PPE & 0.336 & 0.51 \\
Nuritional Status & 0.229 & 0.89 \\
Concentration of Toluene Inhalation & 0.378 & - \\
\hline
\end{tabular}

$\mathrm{PR}=$ Prevalence Risk.

\section{Discussion}

\subsection{Correlation Between Characteristics of Respondents With Neurotoxic Risk}

The majority of respondents age was in the range of 36-45 years. Age also had a significant correlation with 
neurotoxic risk. Metabolism was strongly influenced by genetic factors, labor vulnerability, length of exposure, weight, body composition (body fat), smoking habits and age (ATSDR, 2015). The older the workforce, the greater the effect that will arise due to exposure to toluene, this is due to increasing age, the metabolic system in the body also decreases, so that the metabolism of toluene in the body will also decrease. With increasing age, the anatomic decline and organ function were greater. A theory states that organ function decreased by $1 \%$ annually after 30 years of age (Tamtomo, 2016). The age range of 20-24 years also shows an increase in neurobehavioral disorders due to solvent exposure and constant until the age of 40 (Gamble, 2000).

Majority respondent's working period was more than 18 years. Workers with a tenure of at least 10 years with a high level of exposure to organic solvents have an adverse risk to their health. Another study on the 10-year work period with exposure to organic solvents is considered as a criterion for diagnosing the occurrence of chronic toxic encephalopathy (Lunberg et al., 1997). Workers exposed to high organic solvents may have subtle effects on cognitive functions such as attention, verbal memory and visuospatial abilities (Rahmah, 2012). One important factor of neurotoxic effects is determined by lifetime exposure (cumulative), exposure intensity or peak exposure (Dick, 2006).

As many as $78.1 \%$ of subjects sometimes used standard PPE when working. This was consistent with previous research which states most respondents (95.6\%) always use respiratory protective equipment at work (Rahmah, 2012). Given the absorption of toluene mostly through breathing, it was necessary to control the use of masks while working. From the observation, the mask used by the workers was a surgical mask. Masks that were suitable for working conditions that contain steam or toluene gas should wear a mask equipped with cartridge gas so that the air of inspiration has been purified.

The majority of the study subjects were in the overweight category at BMI measurement, and $25 \%$ each in the obesity category 1 and the normal category. There were also in accordance with other studies research showed that 20 from 33 respondents had a BMI with a normal category, but respondents with BMI $>25$ had the greatest risk of getting health problems due to synergistic effects of toluene exposure (Warsito, 2007). Toluene compounds are lipophilic (fat soluble) so that there were many in people who are fat or overnutrition, meaning that fat will bind toluene into residues in the body. Therefore, the more obese respondents who are exposed to toluene will have a higher health risk due to toluene exposure. The results of this study were similar to study which states that neurological diseases have a relationship with the condition of undernutrition or malnutrition which can cause nerve damage, especially in the peripheral nervous system (Spencer \& Palmer, 2012).

\subsection{Correlation between Toluene Concentration and Neurotoxic Risk}

Toluene was a type of volatile, colorless and commonly used aromatic hydrocarbon used as a paint solvent, a mixture of gasoline, nail polish, and as a solvent in the printing business. According to the American Conference of Governmental Industrial Hygienists Toluene Threshold (TLV) value is $20 \mathrm{ppm}$ for 8 hours/day 40 hours per week based on ACGIH while according to the Minister of Manpower and Transmigration Regulation year 2011, the toluene threshold value is $50 \mathrm{ppm}$ (ACGIH, 2011; Ministry Manpower \& Transmigration of RI, 2011).

Based on the results of measurements of toluene concentration in 4 locations, the printing section of PT. X obtained 1 location with above toluene concentration $(14.92 \mathrm{ppm})$ while the other 3 locations had toluene concentrations below $14.92 \mathrm{ppm}$. The overall measurement results show the toluene concentration was below the threshold value of toluene. This result was similar to previous research which is also still below the toluene threshold set by the Minister of Manpower and Transmigration Regulation (50 ppm) (Agustina, 2016; Badjagbo et al., 2010). Toluene exposure could cause symptoms of acute and chronic poisoning. The initial symptoms of acute poisoning have been observed at exposure to trials conducted by volunteers with an exposure level of about $750 \mathrm{mg} / \mathrm{m}^{3}$ for 8 hours or $1.125 \mathrm{mg} / \mathrm{m}^{3}$ for 20 minutes could cause respiratory tract irritation and eye irritation (IPCS, 1986).

In humans, toluene was found in the arteries in 10 seconds after inhaling toluene vapor (Demir et al., 2017; HPA, 2007). However, when toluene is transmitted through the gastrointestinal tract, toluene was able to reach a maximum peak in the blood for 1-3 hours (Uzun et al., 2001). Toluene absorption through the digestive tract was slower than the respiratory tract (EPA, 2005).

Toluene after absorption can be found in small amounts in fat tissue (white and brown fat tissue), stomach, liver, kidney, bone marrow, brain, and lymph tissue (HPA, 2007). Five hours after toluene is inhaled, toluene will reach the maximum level in adipose tissue. High levels of Toluene can be found in the liver and brain in people with death from toluene inhalation (Eisenberg, 2003).

Several theories mention that toluene shows a neurotoxic effect by increasing the activity of cholinergic bonds 
on the gamma-aminobutyric acid receptor (GABA) and shows noncompetitive antagonistic effects on $\mathrm{N}$-methyl-D-aspartate (NMDA) receptors (Sakai et al., 2000; Thetkathuek et al., 2015). In patients with toluene exposure for 10 years, there is a chronic toluene effect that leads to demyelination and axonal degeneration (Thetkathuek et al.,2015). This study also had similar results with other studies that toluene exposure had a correlation with neuropsychological effects, especially psychosomatic symptoms such as difficult to concentrate, easy to get angry, depressed and sleep disturbances (Karabulut et al., 2009).

Some studies also mention that toluene could cause tissue damaged by increasing oxygen radicals (Calderón et al., 2005). According to another hypothesis, toluene increased the fluidity of membranes by changing the structure of lipids in cell membranes and giving effect to Na/K-ATPase activity (Montgomery et al., 1993). Toluene was nonpolar, while $70 \%$ of the brain's nerves were also non-polar. There was a concept that non-polar toxins could dissolve in nonpolar solvents so that toluene could easily enter the alveoli and experienced blood distribution until it penetrates the brain's nervous system cell membranes (especially nerve myelin) (Meydan et al., 2012). Toluene was also mentioned to have the effect of the GABAergic, glutamatergic, serotonergic, and dopaminergic pathways in high doses (Bowen et al., 2005; Tas et al., 2011). While recent studies indicated toluene can increase apoptosis or cell death (Gotohda et al., 2009). Limitation of this study is the small size of the sample because it was obtained by population sample in plastic sack industry at printing section, measurement of toluene just be done in one time despite using standard tools and professional worker and less of reference based previous study. Despite this limitation, the strength of this study is this topic never be done in Indonesia especially in plastic sack industry where people didn't aware of neurotoxin risk in the place exposure of toluene inhalation. Plastic sack workers at printing section should use PPE regularly (especially masks) to reduce the risk of neurotoxins through toluene inhalation. Further research to find out how the process of toluene exposure affects the risk of neurotoxins also needs to be re-examined, especially industrial sites in Indonesia.

\section{Conclusion}

The majority of the study subjects had an age range of 36-45 years, working period of more than 18 years, sometimes using PPE, and had nutritional status with criteria for fat ( $\geq 23.0-24.9)$. Demographic factors (age, years of work, use of PPE and nutritional status) and concentrations of toluene inhalation have a significant relationship with neurotoxic risk. Continuous toluene exposure can cause apoptosis/damage to the myelin sheath in the nerves so that it can cause neurotoxin risks such as difficult to concentrate, easy to get angry, dementia and sleep disturbances. Plastic sack workers are required to use PPE regularly (especially masks) to reduce the risk of neurotoxins through toluene inhalation. Further research to find out how the process of toluene exposure affects the risk of neurotoxins also needs to be re-examined, especially industrial sites in Indonesia.

\section{Source of Funding}

This is an article "Association between Toluene Inhalation Exposure and Demography towards Risk of Neurotoxic: A Crossectional Study at Pekerja Bagian Printing Industri Karung Plastik, of Occupational Health and Safety Department that was supported by Activity Budget, Plans 2017, Faculty of Public Health, Airlangga University.

\section{Ethical Clearance}

The study was approved by the institutional Ethical Board of the Public Health, Airlangga University with protocol ethics approval number 545-KEPK.

\section{Acknowledgments}

Thanks for Jihan Faradisha, Wulan Meidikayanti and Fatma Tualeka for helping edit this manuscript. Some of the results of this article have been previously published in the results of the thesis "Analysis of the Relationship of Toluene Exposure with Neurotoxic Risks to the Printing Section Workers of Plastic Sack Industry in Pt X Sidoarjo" at repository.unair.ac.id/72780/.

\section{Competing Interests Statement}

All authors have no conflicts of interest to declare.

\section{References}

Agustina, U. (2016). Correlation between Toluene and Urine Hippuric Acid with Central Nervous System Complaints at Workshop Worker. Essay. Surabaya: Faculty of Public Health, Airlangga University.

American Conference of Governmental Industrial Hygienists. (2011). TLVs and BEIs for Chemical Substance and Physical Agents. Cincinnati, Ohio: ACGIH. 
ATSDR. (2015). Toxicological Profile For Toluene [Internet]. United States: US Department. Retrieved August 20, 2018, from https://www.atsdr.cdc.gov/ toxprofiles/tp56.pdf

Badjagbo, K., Loranger, S., Moore, S., et al. (2010). BTEX Exposures Among Automobile Mechanics and Painter and Their Associated Health Risks. Hum Ecol Risk Assess: An Inter J, 16(2), 301-316.

Bowen, S. E., Batis, J. C., Mohammadi, M. H., \& Hannigan, J. H. (2005). Abuse pattern of gestational toluene exposure and early postnatal development in rats. Neurotoxicol Teratol, 27(1), 105-116.

Calderón-Guzmán, D., Espitia-Vázquez, I., López-Domínguez, A., Hernández-García, E., Huerta-Gertrudis, B., Coballase-Urritia, E., ... \& García-Fernández, B. (2005). Effect of toluene and nutritional status on serotonin, lipid peroxidation levels and $\mathrm{Na}+/ \mathrm{K}+-\mathrm{ATPa} e$ in adult rat brain. Neurochemical research, 30(5), 619-624.

Demır, M., Cicek, M., Eser, N., Yoldaş, A., \& Sisman, T. (2017). Effects of acute toluene toxicity on different regions of rabbit brain. Analytical Cellular Pathology, 2017. https://doi.org/10.1155/2017/2805370

Dick, F. D. (2006). Solvent neurotoxicity. Occupational and environmental medicine, 63(3), 221-226. https://doi.org/10.1136/oem.2005.022400

Eisenberg, D. P. (2003). Neurotoxicity and mechanism of toluene abuse. Einstein QJ Biol Med, 19, 150-159.

Filley, C. M., Halliday, W., \& Kleinschmidt-DeMasters, B. K. (2004). The effects of toluene on the central nervous system. Journal of Neuropathology \& Experimental Neurology, 63(1), 1-12. https://doi.org/10.1093/jnen/63.1.1

Gamble, J. F. (2000). Low-level hydrocarbon solvent exposure and neurobehavioural effects. Occupational medicine, 50(2), 81-102.

Gotohda, T., Nishimura, A., \& Morita, K. (2009). Immunohistochemical studies on early stage of hepatic damage induced by subacute inhalation of toluene vapor in rats. Journal of Applied Toxicology, 29(6), 505-509.

Health Protection Agency (HPA). (2007). Toluene Toxicological Overview. Retrieved August 20, 2018, from http://www.hpa.org.uk/web/HPA webFile/HPAweb_C/1194947395545.

Ihrig, A., Triebig, G., \& Dietz, M. C. (2001). Evaluation of a modified German version of the Q16 questionnaire for neurotoxic symptoms in workers exposed to solvents. Occup Environ Med, 58(1), 19-23. https://doi.org/10.1136/oem.58.1.19

International Programme On Chemical Safety Environmental Health Criteria (IPCS). (1986). Toluene: Environmental Health Criteria 52. Geneva: WHO.

Karabulut, I., Balkanci, Z. D., Pehlivanoglu, B., Erdem, A., \& Fadillioglu, E. (2009). Effect of toluene on erythrocyte membrane stability under in vivo and in vitro conditions with assessment of oxidant/antioxidant status. Toxicology and industrial health, 25(8), 545-550.

Lee, J. I., Lee, K. S., Paik, Y. H., Park, Y. N., Han, K. H., Chon, C. Y., \& Moon, Y. M. (2003). Apoptosis of hepatic stellate cells in carbon tetrachloride induced acute liver injury of the rat: analysis of isolated hepatic stellate cells. Journal of hepatology, 39(6), 960-966.

Lundberg, I., Högberg, M., Michelsen, H., Nise, G., \& Hogstedt, C. (1997). Evaluation of the Q16 questionnaire on neurotoxic symptoms and a review of its use. Occupational and environmental medicine, 54(5), 343-350. https://doi.org/10.1136/oem.54.5.343

Meydan, S., Altas, M., Nacar, A., Ozturk, O. H., Tas, U., Zararsiz, I., \& Sarsilmaz, M. (2012). The protective effects of omega-3 fatty acid against toluene-induced neurotoxicity in prefrontal cortex of rats. Human \& experimental toxicology, 31(11), 1179-1185.

Ministry Manpower and Transmigration of Republic Indonesia. (2011). Regulation of Ministry Manpower and Transmigration. Peraturan Menteri Tenaga Kerja dan Transmigrasi Number.13/MEN/X/2011 concerning Threshold Limit Value of Physical and Chemical Factors at Workplace. Indonesia: Ministry Manpower and Transmigration of Republic Indonesia. Retrieved August 20, 2018, from https://betterwork.org/dev/wp-content/uploads/2017/09/4-PERMENA.pdf

Montgomery, R. (Ed.). (1996). Biochemistry: a case-oriented approach. Mosby Incorporated.

Pratamasari, F. (2015). Prevalence of Peripheral Nerves Neuropathy in Offset Printing Workers Exposed to Inhalation Toluene 2015. Thesis. Yogyakarta: Master Program of Occupational Health and Safety, Gajah Mada University. [In Indonesian] 
Hee, S. Q. (Ed.). (1993). Biological monitoring: an introduction. John Wiley \& Sons.

Rahmah, M. D. (2012). Analysis neurotoxic Symptoms caused by Xylene Organic Solvent Exposure at Paint Making Workers. Thesis. Jakarta: Master Program of Occupational Health and Safety, Faculty of Public Health, University of Indonesia. [In Indonesian]

Sakai, T., Honda, S., \& Kuzuhara, S. (2000). Encephalomyelopathy demonstrated on MRI in a case of chronic toluene intoxication. Clin Neurol, 40(6), 571-575.

Sarwono, J. (2006). Methods of Quantitative and Qualitative Research. Yogyakarta: Graha Ilmu.

Spencer, P. S., \& Palmer, V. S. (2012). Interrelationships of undernutrition and neurotoxicity: food for thought and research attention. Neurotoxicology, 33(3), 605-616. https://doi.org/10.1016/j.neuro.2012.02.015

Tamtomo, D. G. (2016). Changes in Anatomy of Body Organs in Aging. In Inaugural Lectures. University of Sebelas Maret Surakarta.. Retrieved August 20, 2018, from https://library.uns.ac.id/perubahan-anatomik-organ-tubuh-pada-penuaan/[In Indonesian]

Tas, U., Ogeturk, M., Meydan, S., Kus, I., Kuloglu, T., Ilhan, N., ... \& Sarsilmaz, M. (2011). Hepatotoxic activity of toluene inhalation and protective role of melatonin. Toxicology and Industrial Health, 27(5), 465-473.

Thetkathuek, A., Jaidee, W., Saowakhontha, S., \& Ekburanawat, W. (2015). Neuropsychological symptoms among workers exposed to toluene and xylene in two paint manufacturing factories in eastern Thailand. Advances in preventive medicine, 2015. https://doi.org/10.1155/2015/183728

Tualeka, A. R., Irianto, M. A., Prasetyo, A., Rachmawati, I. A., \& Nawawinetu, E. D. (2018). Detoxification of Benzoic Acid in Workers Exposed to Toluene Using Food Rich in Glycine. Indian Journal of Public Health Research \& Development, $9(1)$.

United States. (2005). Environmental Protection Agency (EPA) Toxicological Review of Toluene. Retrieved August 20, 2018, from http://www.epa.gov/iris/toxreviews/0118-tr.pdf.

Uzun, N., Karaali, S. F., \& Kiziltan, M. E. (2001). Peripheral nerve system damage in chronic toluene and n-hexane intoxication: electrophysiologic investigation. Cerrahpasa J Med, 32, 142-150.

Warsito, A. (2007). Analysis of Toluene Exposure to Blood Profiles at Petroleum Refining Industry Workers. Thesis. Semarang: Master Program of Environmental Health. University of Diponegoro. [In Indonesian]

World Health Organization [WHO]. (2000). The Asia-Pacific Perspective: Redefining Obesity and Its Treatment [Internet]. Western Pacific Region: IASO International Association for the study of Obesity. Retrieved August 20, 2018, from on http://www.wpro.who.int/nutrition/documents/docs/Redefiningobesity.pdf

\section{Copyrights}

Copyright for this article is retained by the author(s), with first publication rights granted to the journal.

This is an open-access article distributed under the terms and conditions of the Creative Commons Attribution license (http://creativecommons.org/licenses/by/4.0/). 